\title{
Pendugaan Parameter Populasi Ikan Kembung yang Didaratkan di PPN Ternate dan Pasar Higienis Kota Ternate
}

\author{
Mariam Hi. M. Nur ${ }^{1}$, Umar Tangke ${ }^{2 \bowtie}$, dan Djabaluddin Namsa ${ }^{2}$ \\ 1 Mahasiswa Program Studi Teknologi Hasil Perikanan, Fakultas Pertanian dan Perikanan, Universitas Muhammadiyah \\ Maluku Utara. Ternate, Indonesia. \\ 2 Staf Pengajar Program Studi Teknologi Hasil Perikanan, Fakultas Pertanian dan Perikanan, Universitas Muhammadiyah \\ Maluku Utara. Ternate, Indonesia. \\ Email : umbakhaka@gmail.com
}

${ }^{\square}$ Korespondensi : Umar Tangke, Universitas Muhammadiyah Maluku Utara. Ternate, Indonesia,
Email : umbakhaka@gmail.com

\begin{abstract}
ABSTRAK
Produksi ikan kembung di Kota Ternate dengan menggunakan alat tangkap hand line terus meningkat seiring dengan bertambahnya jumlah trip maupun unit alat tangkap karena ikan kembung mempunyai nilai ekonomis tinggi serta peluang pasar yang besar, tetapi dalam produksinya nelayan hanya mengandalkan hasil tangkapan yang berasal dari alam dan dilakukan secara terus menerus, sehingga dikhawatirkan akan menimbulkan dampak negatif terhadap distribusi dan kondisi populasinya. Pengumpulan data panjang ikan kembung selama bulan November sampai desember 2020 di PPN Ternate, Pasar Higiensi dilakukan untuk pendugaan prameter populasi ikan kembung dan tingkat eksploitasi di perairan Pulau Ternate meliputi kelompok umur, pertumbuhan, mortalitas, dan yield per recruitment di Perairan Pulau Ternate dan dapat dijadikan sebagai bahan informasi bagi Pemerintah Daerah dan nelayan sebagai acuan dalam pengelolaan sumberdaya ikan kembung secara optimal. Hasil penelitian didapat bahwa pendugaan parameter pertumbuhan ikan kembung yang didaratkan di Kota Ternate memiliki panjang maksimum, dengan mortalitas alami dari ikan kembung, $\mathrm{M}$ $=0.02$ per tahun dan mortalitas penangkapan $\mathrm{F}=13.5$ per tahun maka diperoleh nilai tingkat eksploitasi $\mathrm{E}=0.46$. laju eksploitasi tersebut mengindikasikan bahwa tingkat eksploitasi ikan kembung sudah mendekati nilai maksimum $(E=0,50)$. sedangkan nilai $B / R$ didapatkan sebesar 0.5 dimana nilai tersebut menunjukan bahwa biomas yang tersisa dari ikan yang masuk ke perairan sebesar $50 \%$ hal ini menunjukan bahwa tingkat eksploitasi sudah mengalami overfishing atau lebih dari 0.46 (46\%) karena tingkat eksploitasi saat ini sudah mencapai 0.68.
\end{abstract}

Keyword: Ikan kembung, Rastreligger, PPN Ternate, Pasar higienis

\section{PENDAHULUAN}

Perairan Pulau Kota Ternate adalah bagian dari Provinsi Maluku Utara dan merupakan salah satu perairan yang sangat berperan dalam menyumbang produksi perikanan tangkap khususnya jenis ikan pelagis dan ikan demersal. Potensi perikanan tangkap perairan Pulau Kota Ternate diperkirakan sebesar 47.838,25 ton/tahun dan baru dimanfaatkan sebesar 23.919,25 ton/tahun. Jenis ikan yang tersebar di perairan Pulau Kota Ternate adalah ikan pelagis besar diantaranya ikan tuna, ikan cakalang, ikan tongkol dan ikan tenggiri dengan potensi per tahun mencapai 211.590,00 ton. Selain itu jenis ikan pelagis kecil diantaranya ikan teri, ikan kembung, ikan layang, ikan selar dan ikan julung juga memiliki potensi yang cukup besar yakni sebesar 169.834,33 ton per tahun (DKP Kota Ternate, 2017).

Ikan kembung atau lebih dikenal dengan nama ilmiah Rastreliger spp merupakan salah satu komunitas perikanan pelagis kecil yang penting, dimana ikan ini termasuk jenis pemakan zooplankton, hidup didekat daerah permukaan laut (pelagis) yang berkadar garam tinggi dan membentuk gerombolan besar (Sunarjo, 1990). Secara ekologis, ikan kembung termasuk jenis ikan perenang cepat, bersifat pelagis, tidak menetap dan suka bergerombol, dimana sebagai jenis ikan yang suka bergerombol dan pemanfaatannya menggunakan alat tangkap yang aktif seperti bagan perahu, gill net dan pancing, sehingga dikhawatirkan akan menimbulkan dampak negatif terhadap distribusi dan 
kondisi populasinya, jika permintaan ikan sebagai sumber protein terus meningkat tanpa adanya pengelolaan secara berkelanjutan maka akan berdampak pada populasi ikan kembung tersebut.

Untuk pengelolaan berkelanjutan diperlukan informasi menyangkut parameter populasi seperti kelompok umur, pertumbuhan, mortalitas dan yield per recruit. Penentuan umur, pertumbuhan, mortalitas dan yield per recruit merupakan hal yang mendasar pada ilmu perikanan, dimana pada stadia awal dari sumberdaya ikan, informasi struktur umur digunakan untuk menjelaskan pengaruh perubahan lingkungan pada pertumbuhan dan kelangsungan hidup serta dapat memahami faktor-faktor yang mempengaruhi keberhasilan rekruitmen, sedangkan pada fase dewasa pengetahuan tentang umur dan pertumbuhan digunakan untuk menduga pengaruh penangkapan terhadap stock dan kebijaksanaan dalam manajemen pengelolaan.

Pertumbuhan dalam dinamika populasi sangat penting karena laju pertumbuhan mempengaruhi kondisi organisme saat pertama kali bertelur (kematangan), komposisi umur stock atau rekruitmen kedalam stock, potensi hasil dari suatu stock dan mortalitas. Analisis pertumbuhan pada dasarnya menyangkut penentuan ukuran badan sebagai suatu fungsi dari umur, oleh karena itu semua metode-metode pengkajian stock (stock assessment) pada intinya bekerja dengan data komposisi umur. Oleh karena itu untuk kepentingan pengelolaan sumberdaya ikan kembung yang didaratkan di PPN Ternate dan Pasar Higienis agar pemanfaatannya dapat berkelanjutan, maka perlu dikaji informasi paramater populasinya. Penelitian ini bertujuan untuk mengkaji parameter dinamika populasi ikan kembung yang didaratkan di Pelabuhan Perikanan Nusantara Ternate dan Pasar Higienis Kota Ternate Provinsi Maluku Utara. Sedangkan penelitian ini dapat di gunakan sebagai suatu informasi tentang dinamika populasi ikan kembung dalam pemanfaatan ikan kembung secara berkelanjutan

\section{METODE PENELITIAN}

Penelitian ini dilaksanakan pada bulan November sampai Desember 2020. bertempat di Pelabuhan Perikanan Nusantara (PPN) Ternate dan Pasar Higienis Kota Ternate. Alat dan bahan yang digunakan dalam penelitian ini terdiri dari alat tulis menulis, camera android, ikan kembung, kuisioner, computer, aplikasi 3d-camera measurement dan sofwere Fisat II. Prosedur penelitian dapat dilihat pada Gambar 1.

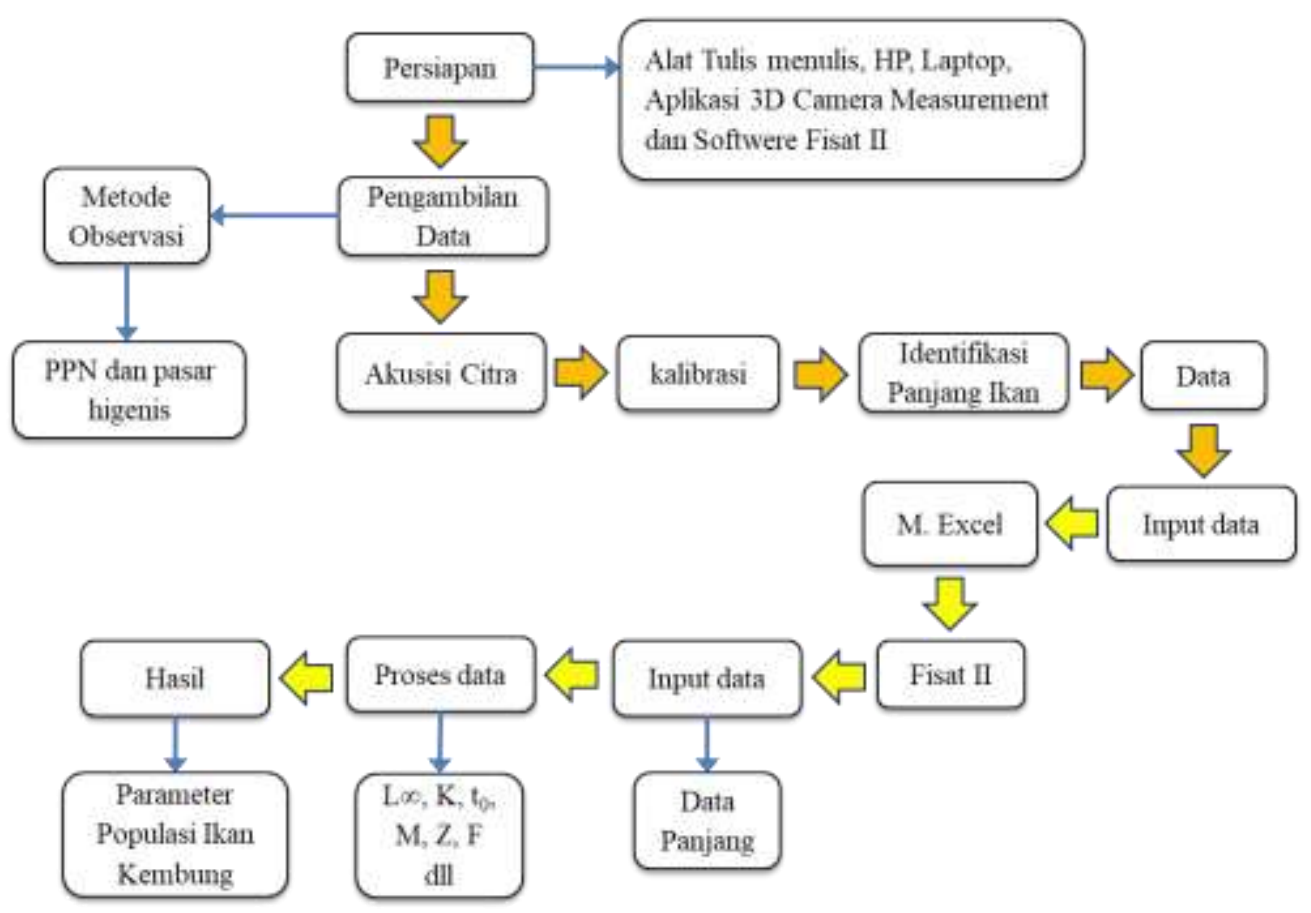

Gambar 1. Prosedur Penelitian 
Prosedur penelitian dimulai dari proses pengambilan data, identifikasi panjang dan analisis data yang dimulai dari persiapan awal yakni menyiapakan peralatan, aplikasi dan softwere penelitian berupa HP android dan aplikasi 3D-camera measurment dan 1 unit komputer/laptop serta softwere Fisat II. Proses selanjutnya adalah pengumpulan data penelitian dengan melakukan dokumentasi di pasar Higenis dan PPN Ternate untuk identifikan panjang ikan kembung. Proses pengumpulan data dilakukan dengan metode observasi yaitu melakukan kunjungan ke tempat Pelabuhan Perikanan Nusantara Ternate (PPN) dan pasar Higienis di Kota Ternate untuk mendapatkan data ikan kembung. Tahap selanjutnya adalah proses akuisisi citra berupa pengambilan (capturing) citra dari suatu objek ikan melalui pengambilan photo menggunakan kamera handphone. 3D-camera measurement ikan yang diperoleh dilanjutkan ke tahap praprocessing yaitu melakukan identifikasi ukuran panjang ikan dengan menggunakan aplikasi $3 D$ Camera measurement, untuk menghasilkan data panjang yang selanjutnya diolah dengan menggunakan softwere FiSAT II untuk proses analisis parameter populasinya. Proses kerja pada penelitian dapat dlihat pada Gambar 1.

Data Penelitian selanjutnya di analisis melalu beberapa tahap diantaranya :

\section{Sebaran Frekuensi Panjang}

Penentuan distribusi frekuensi panjang ikan menggunakan data panjang total ikan kembung yang ditangkap di perairan teluk dodinga dan didaratkan di pasar Higienis kota Ternate. Tahap untuk menganalisis data frekuensi panjang ikan yaitu : (a) menentukan jumlah selang kelas yang diperlukan; (b) menentukan lebar selang kelas; (c) menentukan frekuensi dan memasukan frekuensi masingmasing kelas panjang dengan mernasukkan panjang dan masing-masing ikan contoh pada selang kelas yang telah ditentukan.

Sebaran frekuensi panjang yang telah di tentukan dalam selang kelas panjang yang sama, kemudian diplotkan dalam sebuah grafik, dimana pada grafik tersebut dapat diduga pergeseran sebaran kelas panjang setiap pengambilan contoh, yang menggambarkan jumlah kelompok umur ( $k o h o r t$ ) yang ada dalam perubahan posisi ukuran panjang kelompok umur yang sama.

\section{Identifikasi Kelompok}

Pendugaan kelompok umur ukuran dilakukan dengan menganalisis frekuensi panjang ikan kembung. Data frekuensi di analisis dengan menggunakan salah satu metode yang terdapat dalam program FiSAT II (FAO-ICLARM Stok assesment tool) yaitu metode NORMSEP (Normal separtion). Sebaran frekuensi panjang dikelompokan kedalam beberapa kelompok umur yang di asumsikan penyebaran normal, masing-masing di cirikan oleh rata-rata panjang dan di simpangan baku.

Menurut Boer (1996) jika $f_{1}$ adalah frekuensi ikan dalam kelas panjang ke-i $(i=1,2 \ldots . N) . \mu_{\mathrm{J}}$ adalah rata-rata panjang kelompok umur ke- $j, \breve{O}_{j}$ simpangan baku panjang kelompok umur ke-j dan $p_{j}$ adalah proporsi ikan dalam kelompok umur ke-j $(j=1,2 \ldots G)$, maka fungsi objektif yang di gunakan untuk menduga $\left\{\mu_{\mathrm{j}, \mathrm{o} \mathrm{j}}, \mathrm{p}_{\mathrm{j}}\right\}$ adalah fungsi kemungkinan maksimum (maximum likelihood function) :

$\mathrm{L}=\sum_{1=1}^{N} F 1 \log \sum_{J=1}^{G} p j q u$, sedangkan $\mathrm{q}_{\mathrm{ij}}=\frac{1}{G J \sqrt{2 \pi}} \mathrm{G}-\frac{1}{2}\left(\frac{X i-u j}{G J}\right)^{2}$ yang merupakan fungsi kesepekatan sebaran normal dengan nilai tengah $\mathrm{u}_{\mathrm{j}}$ dan sipangan baku $\breve{\mathrm{O}}_{\mathrm{j}} X_{i}$ adalah titik tengah kelas panjang ke-j. Fungsi opjektif L ditentukan dengan cara mencari turunan pertama L masing-masing

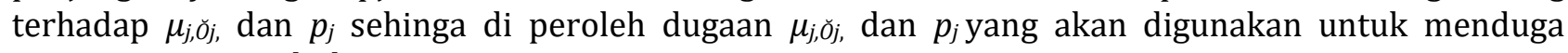
parameter pertumbuhan.

\section{Pendugaan parameter pertumbuhan}

Untuk menduga pertumbuhan digunakan formula yang dikemukakan oleh Von Bertalanffy (Sparre dan Venema, 1999) dengan persamaan sebagai berikut :

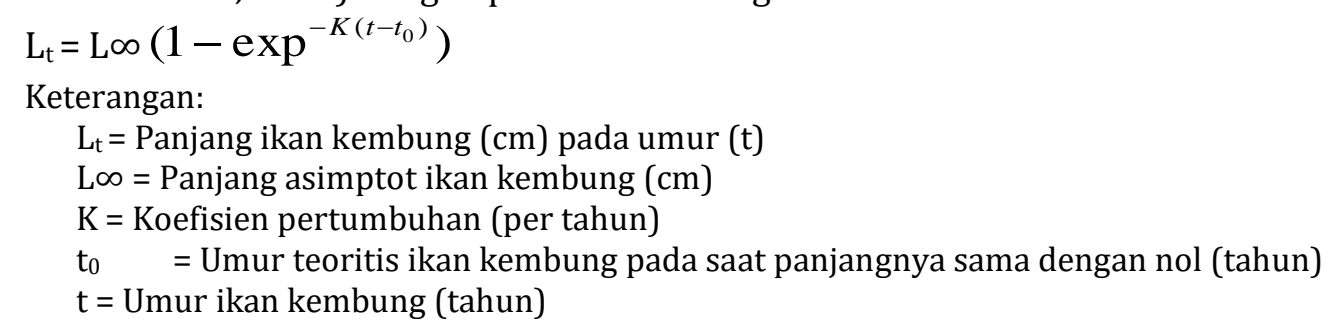


Sedangkan untuk menentukan panjang asimtot ikan kembung (Lo) dan koefisien laju pertumbuhan (K) digunakan metode Ford dan Walford dalam Sparre dan Venema (1999) yaitu dengan memplotkan $\mathrm{L}(\mathrm{t}+\Delta \mathrm{t})$ dan $\mathrm{L}(\mathrm{t})$ dengan persamaan berikut :

$\mathrm{L}(\mathrm{t}+\Delta \mathrm{t})=\mathrm{a}+\mathrm{b} \cdot \mathrm{L}(\mathrm{t})$

Setelah mendapatkan persaman regresi dari kedua hubungan kemudian dimasukkan ke dalam persamaan linier yaitu :

$$
\mathrm{Y}=\mathrm{a}+\mathrm{bX}
$$

Dimana:

$$
\mathrm{a}=\mathrm{L} \infty(1-\mathrm{b}) \mathrm{b}=\exp (-\mathrm{K} . \Delta \mathrm{t})
$$

sehingga diperoleh :

$$
\mathrm{L} \infty=\frac{a}{1-b} \mathrm{~K}=\frac{-1}{\Delta t} \mathrm{Ln} \mathrm{b}
$$

Selanjutnya pendugaan umur teoritis pada saat panjang ikan kembung sama dengan nol $\left(t_{0}\right)$ digunakan rumus empiris Pauly dalam Sparre dan Venema, (1999) sebagai berikut:

$$
\log \left(-\mathrm{t}_{0}\right)=-0,3922-0,2752 \log \mathrm{L} \infty-1,308 \log \mathrm{K}
$$

Keterangan:

L $\infty=$ Panjang asimptot ikan kembung $(\mathrm{cm})$

$\mathrm{K}=$ Koefisien pertumbuhan (per tahun)

$\mathrm{t}_{0}=$ Umur teoritis ikan kembung pada saat panjangnya sama dengan nol (tahun)

\section{Pendugaan mortalitas alami (M)}

Laju mortalitas alami (M) diduga dengan menggunakan rumus empiris rumus empiris Pauly (1983) adalah sebagai berikut :

$\ln \mathrm{M}=\quad-0,152-0,279 \ln \mathrm{L} \infty+0,6543 \ln \mathrm{K}+0,4634 \ln \mathrm{T}$

Keterangan:

$$
\begin{aligned}
& \mathrm{M}=\text { Mortalitas alami (per tahun) } \\
& \mathrm{L} \infty=\text { Panjang asimptot ikan kembung }(\mathrm{cm}) \\
& \mathrm{K}=\text { Koefisien pertumbuhan (per tahun) } \\
& \mathrm{T}=\text { Suhu permukaan rata-rata tahunan }\left({ }^{\circ} \mathrm{C}\right)
\end{aligned}
$$

\section{Pendugaan mortalitas total ( $Z$ )}

Pendugaan laju kematian total $(\mathrm{Z})$ dianalisis dengan menggunakan metode Baverton dan Holt (Sparre dan Venema, 1999), dimana formula yang dipergunakan adalah :

$$
Z=K\left[\frac{L \infty-\bar{L}}{\bar{L}-L^{\prime}}\right]
$$

Keterangan:

$$
\begin{array}{ll}
\mathrm{Z} & =\text { Laju kematian total ( pertahun) } \\
\mathrm{L} \infty & =\text { Panjang asimptot ikan kembung }(\mathrm{cm}) \\
\mathrm{K} & =\text { Koefisien laju pertumbuhan (per tahun) } \\
\bar{L} & =\text { Panjang rata-rata ikan kembung yang tertangkap }(\mathrm{cm}) \\
L^{\prime} & \quad=\text { Batas terkecil dari panjang tubuh ikan kembung yang tertangkap secara penuh }(\mathrm{cm}) .
\end{array}
$$

\section{Pendugaan mortalitas Penangkapan ( F)}

Mortalitas penangkapan diperoleh dengan persamaan $\mathrm{Z}=\mathrm{F}+\mathrm{M}$, sehingga $\mathrm{F}=\mathrm{Z}-\mathrm{M}$ dan laju eksploitasi (E) diperoleh dengan menggunakan rumus Beverton dan Holt yaitu $E=F / Z$, dimana $F$ adalah nilai mortalitas penangkapan dan Z adalah mortalitas total (Sparre dan Venema, 1999).

\section{Yield Per Recruitment}

Diperoleh dengan menggunakan persamaan Baverton dan Holt (Sparre et al, 1999).

$$
\begin{aligned}
& Y / R=E \cdot U^{M / K}\left(1-\frac{3 U}{1+m}+\frac{3 U^{2}}{1+2 m}-\frac{U^{3}}{1+3 m}\right) \\
& U=1-\frac{L^{\prime}}{L \infty}
\end{aligned}
$$




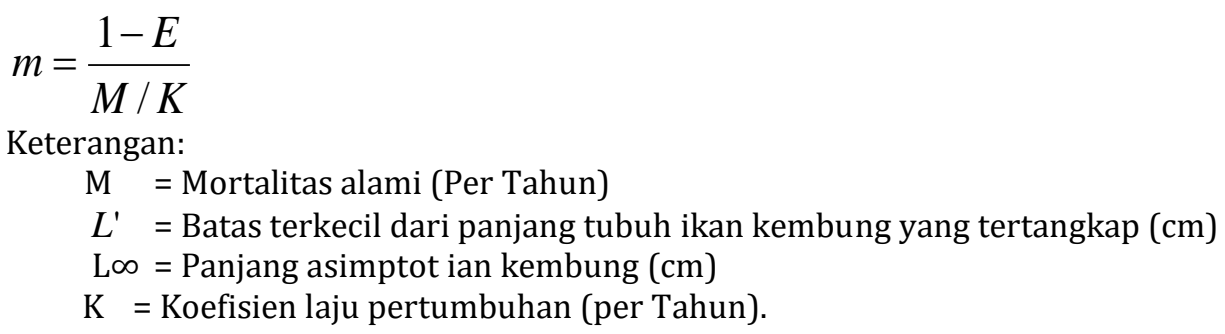

\section{HASIL DAN PEMBAHASAAN}

\subsection{Produksi Ikan Kembung}

Ikan-ikan yang didominan didaratkan diPPN Ternate adalah jenis ikan pelagis dan demersal. Ikan kembung merupakan ikan dengan hasil tangkapan yang dibilang cukup banyak diPPN Ternate dengan persentasi hasil tangkapan ikan kembung sebesar 13\% dari total tangkapan keseluruhan pada tahun 2020.Alat tangkapan utama yang digunakan untuk menangkap ikan pancing ulur (Hand Line), gill net ( jaring insang), purse seine (pukat cincin).

\subsection{Analisis Dinamika Populasi Ikan Kembung (Rastreliger spp)}

\subsubsection{Sebaran Frekunesi Panjang}

Penentuan distribusi frekuensi menggunakan data panjang total ikan kembung yang ditangkap didaratkan di PPN dan pasar Higienis kota Ternate. Tahap menganalisis data frekuensi panjang ikan yakni menentukan jumlah selang kelas yang diperlukan, menentukan lebar selang kelas dan menentukan frekuensi serta memasukan nilai frekuensi masing-masing kelas panjang dengan mernasukkan panjang dan masing-masing ikan contoh pada selang kelas yang telah ditentukan. Sebaran frekuensi panjang selanjutnya diplotkan dalam sebuah grafik.

Berdasarkan hasil analisis ukuran kelas ikan kembung menunjukan bahwa distribusi frekuensi panjang tubuh total, tengah kelas dan nilai selisih logaritma frekuensi ikan kembung yang terkumpul selama penelitian dapat dilihat pada Tabel 1.

Tabel 1. Distribusi Frekuensi Panjang Ikan, Interval Kelas, Tengah Kelas dan Persentase Ikan Kembung

\begin{tabular}{|c|c|c|c|c|c|c|c|c|c|c|}
\hline \multicolumn{3}{|c|}{$\begin{array}{c}\text { Interval } \\
\text { Kelas (cm) }\end{array}$} & \multirow{2}{*}{$\begin{array}{l}\text { TK } \\
3.5\end{array}$} & \multirow{2}{*}{$\begin{array}{c}\begin{array}{c}\mathbf{F} \\
\text { (Ekor) }\end{array} \\
1\end{array}$} & \multirow{2}{*}{$\begin{array}{c}\begin{array}{c}\text { Pers. } \\
\text { (\%) }\end{array} \\
0.06\end{array}$} & \multicolumn{2}{|c|}{$\begin{array}{l}\text { Interval Kelas } \\
\text { (cm) }\end{array}$} & \multirow{2}{*}{$\begin{array}{c}\text { TK } \\
22.5\end{array}$} & \multirow{2}{*}{$\begin{array}{c}\begin{array}{c}\mathbf{F} \\
\text { (Ekor) }\end{array} \\
187\end{array}$} & \multirow{2}{*}{$\begin{array}{c}\begin{array}{c}\text { Pers. } \\
\text { (\%) }\end{array} \\
10.36\end{array}$} \\
\hline 3 & - & 4 & & & & 22 & 23 & & & \\
\hline 4 & - & 5 & 4.5 & 2 & 0.11 & 23 & 24 & 23.5 & 154 & 8.53 \\
\hline 5 & - & 6 & 5.5 & 4 & 0.22 & 24 & 25 & 24.5 & 97 & 5.37 \\
\hline 6 & - & 7 & 6.5 & 4 & 0.22 & 25 & 26 & 25.5 & 64 & 3.55 \\
\hline 7 & - & 8 & 7.5 & 5 & 0.28 & 26 & 27 & 26.5 & 43 & 2.38 \\
\hline 8 & - & 9 & 8.5 & 9 & 0.50 & 27 & 28 & 27.5 & 24 & 1.33 \\
\hline 9 & - & 10 & 9.5 & 12 & 0.66 & 28 & 29 & 28.5 & 7 & 0.39 \\
\hline 10 & - & 11 & 10.5 & 18 & 1.00 & 29 & 30 & 29.5 & 18 & 1.00 \\
\hline 11 & - & 12 & 11.5 & 9 & 0.50 & 30 & 31 & 30.5 & 34 & 1.88 \\
\hline 12 & - & 13 & 12.5 & 7 & 0.39 & 31 & 32 & 31.5 & 65 & 3.60 \\
\hline 13 & - & 14 & 13.5 & 19 & 1.05 & 32 & 33 & 32.5 & 89 & 4.93 \\
\hline 14 & - & 15 & 14.5 & 65 & 3.60 & 33 & 34 & 33.5 & 46 & 2.55 \\
\hline 15 & - & 16 & 15.5 & 134 & 7.42 & 34 & 35 & 34.5 & 36 & 1.99 \\
\hline 16 & - & 17 & 16.5 & 117 & 6.48 & 35 & 36 & 35.5 & 22 & 1.22 \\
\hline 17 & - & 18 & 17.5 & 76 & 4.21 & 36 & 37 & 36.5 & 17 & 0.94 \\
\hline 18 & - & 19 & 18.5 & 54 & 2.99 & 37 & 38 & 37.5 & 12 & 0.66 \\
\hline 19 & - & 20 & 19.5 & 34 & 1.88 & 38 & 39 & 38.5 & 8 & 0.44 \\
\hline 20 & - & 21 & 20.5 & 78 & 4.32 & 39 & 40 & 39.5 & 3 & 0.17 \\
\hline 21 & - & 22 & 21.5 & 231 & 12.80 & & & & & \\
\hline
\end{tabular}




\section{Jumlah $\quad 1.805 \quad 100$}

Berdasarkan Interval kelas yang ada, frekuensi terbanyak terdapat pada kisaran panjang tubuh 21 - $22 \mathrm{~cm}$ sebanyak 231 ekor ikan kembung atau sekitar $12.80 \%$, sedangkan frekuensi paling sedikit terdapat pada kisaran panjang tubuh $3-4 \mathrm{~cm}$ sebanyak 1 ekor atau sekitar $0.06 \%$. Hal ini menunjukan bahwa ikan yang paling banyak tertangkap adalah ikan yang belum layak tangkap, menurut Abubakar dkk (2019), ukuran pertama kali matang gonad ikan kembung di perairan Halmahera Barat adalah $25.07 \mathrm{~cm}$. Selanjutnya dari data tersebut didapat bahwa ukuran persentase ikan kembung belum layak tangkap (ukuran $3-24 \mathrm{~cm}$ ) dan ikan layak tangkap (ukuran $24-40 \mathrm{~cm}$ ) masing-masing adalah 67.59 $\%$ (1.224 ekor) dan 32.14\% (585 ekor).

\subsubsection{Kelompok Umur}

Jumlah sampel ikan kembung (Rastrelliger $s p$ ) yang diukur selama penelitian (bulan November Desember 2020) adalah 1.805 ekor dengan kisaran panjang total $3 \mathrm{~cm}$ sampai $40 \mathrm{~cm}$, yang kemudian di kelompok kedalam 4 kelompok umur. Berdasarkan hasil analisis Bhattacharya (Psare dan Venema, 1999) dalam Monoarfa (2013), ikan kembung masing-masing umur relatif satu tahun, dua tahun, tiga dan 4 tahun di PPN Ternate dan Pasar Higienis dengan menggunakan hasil pemetaan selisih logaritma terhadap nilai tengah kelas diperoleh panjang rata-rata dari setiap kelompok umur pada ikan kembung, dengan ukuran rata-rata panjang tubuh masing-masing $L_{1} 9,84 \mathrm{~cm}$, dengan kisaran panjang antara $3-13 \mathrm{~cm}$; $\mathrm{L}_{2} 16.89 \mathrm{~cm}$ dengan kisaran panjang antara $13-20 \mathrm{~cm}, \mathrm{~L}_{3} 23.30 \mathrm{~cm}$ dengan kisaran panjang antara $20-29 \mathrm{~cm}$ dan $\mathrm{L}_{4} 33.42 \mathrm{~cm}$ dengan kisaran panjang $29-40 \mathrm{~cm}$ (Gambar 2).

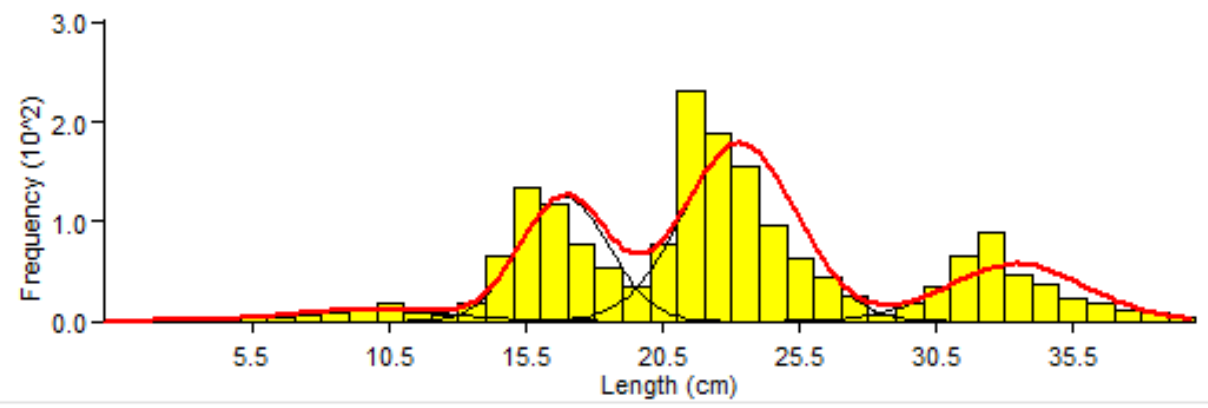

Gambar 2. Sebaran Kelompok Umur Ikan Kembung yang didaratkan di PPN Ternate dan Pasar Higienis

\subsubsection{Pertumbuhan}

Ikan kembung yang diamati selama penelitian sebanyak 1.805 ekor selam bulan November Desember 2020, dimana jumlah ikan yang diamati diperoleh dari PPN Ternate dan Pasar Higienis. Proses analisis pemisahan kelompok umur ikan kembung menggunakan metode ELEFAN I dan hasilnya disajikan pada Gambar 3.

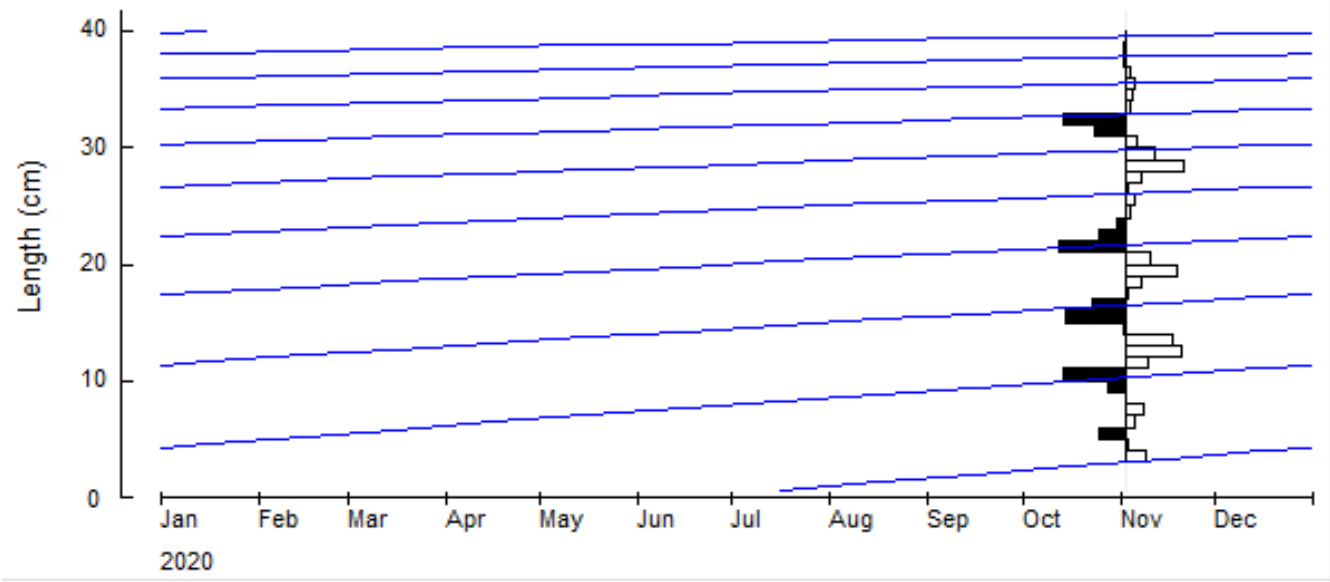

Gambar 3. Sebaran Frekuensi Panjang Ikan Kembung 
Pertumbuhan ialah pertambahan ukuran panjang atau berat dalam suatu waktu (Effendie, 2002), selanjutnya pertumbuhan mempengaruhi stok ikan disuatu daerah dimana pertumbuhan berpengaruh positif terhadap stok, tetapi pertumbuhan tidak menambah jumlah stok, melainkan menambah biomassa suatu stok (Palla dan Wolff, 2007). Hasil analisis parameter pertumbuhan (Lo dan K) dengan metode ELEFAN I yang terdapat dalam program FISAT II, didapat nilai L $\infty=49.75 \mathrm{~cm}$ dengan nila $\mathrm{K}=0,17$ per bulan. Nilai $L \infty$ dan $\mathrm{K}$ ditentukan berdasarkan nilai Rn terbesar (Tangke, 2014) sedangkan nilai $t_{0}$ didapatkan dengan mengunakan rumus empiris Pauly yaitu -1.4.

Nilai dugaan parameter pertumbuhan yang telah diperoleh ( $L \infty, K$ dan $t_{0}$ ) kemudian

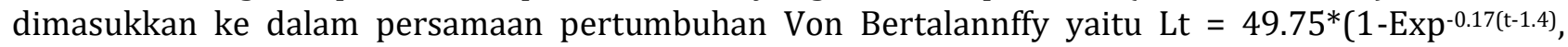
maka dapat dibuat kurva pertumbuhan ikan kembung yang didaratkan di PPN Ternate dan Pasar Higienis Kota Ternate (Gambar 4 ) dengan cara mensubtitusi berbagai tingkat umur ke dalam nilai t.

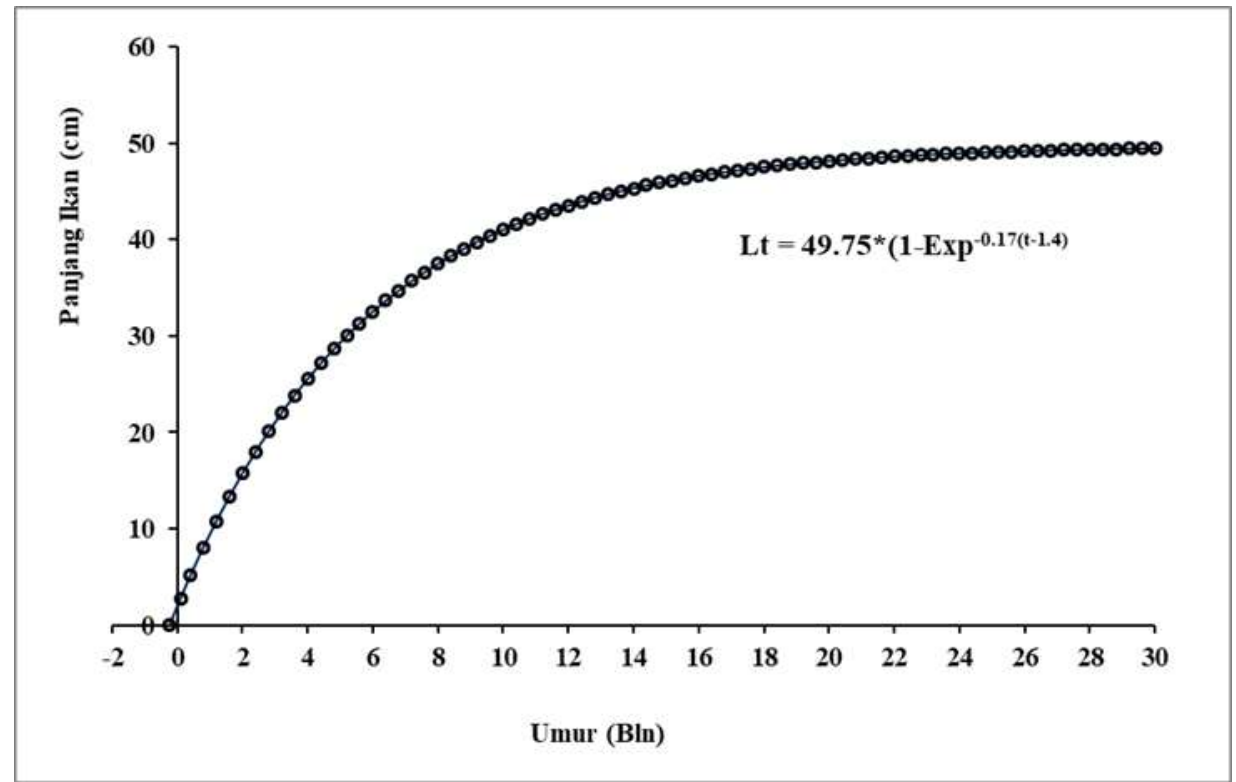

Gambar 4. Kurva pertumbuhan ikan kembung yang didaratkan di PPN Ternate dan Pasar Higienis

Gambar 4 dapat dilihat bahwa kurva pertumbuhan ikan kembung, dimana ikan kembung akan mencapai panjang maksimum secara teoritis pada ukuran $49.75 \mathrm{~cm}$. Kurva tersebut juga menunjukkan bahwa laju pertumbuhan ikan kembung berbeda setiap waktu. Ikan kembung pada waktu muda mengalami laju pertumbuhan lebih cepat dibandingkan pada waktu tua. Effendie (2002) bahwa pertumbuhan cepat terjadi pada ikan ketika berumur 3 - 5 tahun. Pada ikan tua walaupun pertumbuhan itu terus tetapi berjalan dengan lambat. Pada ikan tua energi yang didapatkan dari makanan tidak lagi digunakan untuk pertumbuhannya, tetapi hanya digunakan untuk pergerakan, mengganti sel-sel yang rusak dan kematangan gonad.

Dugaan persamaan pertumbuhan jika dibuat hubungan umur terhadap panjang tubuh ikan kembung, maka terlihat bahwa populasi ikan kembung yang didaratkan di PPN Ternate dan Pasar Higienis kota Ternate dapat mencapai panjang maksimum pada umur 52.8 bulan (4.4 tahun). Nilai dugaan parameter pertumbuhan $\mathrm{L} \infty=49.75$ dan $\mathrm{K}=0.17$ per bulan, jika dibandingkan dengan nilai $\mathrm{L} \infty$ dan nilai $\mathrm{K}$ yang didapat oleh peneliti lainnya pada spesies yang sama di perairan yang berbeda seperti pada Tabel 2 .

Tabel 2. Nilai Loo dan nilai K dari Beberapa Hasil penelitian Ikan Kembung

\begin{tabular}{lccc}
\hline \multicolumn{1}{c}{ Nama Peneliti } & Tahun & Lo & $\mathrm{K}$ \\
\hline Mose dan Hutubessy & 1996 & 33 & 1.37 \\
Nurhakim & 1993 & 26.33 & 0.759 \\
Suhendra dan Amin & 1990 & 24.70 & 1.15 \\
Suwarno & 2010 & 21.6 & \\
Tangke & 2014 & 28.46 & 0.710 \\
Penelitian ini & 2020 & 49.75 & 0.17 \\
\hline
\end{tabular}


Berdasarkan Tabel 2 dapat dilihat bahwa nilai Lo ikan kembung dari hasil penelitian ini lebih besar dari nilai Lo dan K hasil penelitian Mose dan Hutubessy di perairan pulau Ambon, Nurhakim di Laut Jawa serta Suhendra dan Amin di Selat Malaka, Suwarso di Teluk Jakarta serta Tangke di perairan pulau Ternate hal ini menjelaskan ikan kembung yang didaratkan di PPN Ternate dan Pasar Higienis (2020) mempunyai pertumbuhan yang lebih baik dibandingkan dengan ikan kembung yang tertangkap di perairan pulau Ambon, Laut Jawa, Selat Malaka, Teluk Jakarta dan Peraian Pulau Ternate pada tahun 2014. Tingginya nilai parameter pertumbuhan ikan kembung ini diduga ada hubungannya dengan faktor kondisi ekobiologi dari habitat perairan pada saat ini.

\subsubsection{Rekruitmen}

Analisis pola rekruitmen ikan kembung pada penelitian ini menggunakan recruitment pattern analisys pada program Fisat II dengan memasukan nilai $\mathrm{k}$ dan Loo. hasil analisis didapatkan 30\% kohort (Gambar 5), dimana setiap batang pada gambar menjelaskan dugaan rekruitment yang terjadi pada kurung waktu 1 tahun pada setiap bulannya. gambar tesebut menunjukan pada bulan Juli merupakan proporsi tertinggi membentuk puncak yang diduga terjadi rekruitmen.

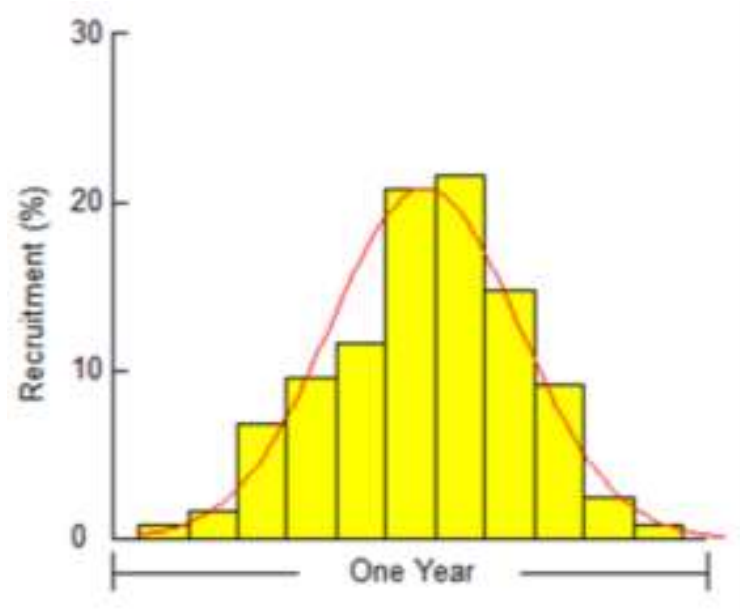

Gambar 5 .Grafik Pola Rekruitmen Ikan Kembung

\subsubsection{Mortalitas}

Suatu stock yang telah dieksploitasi perlu dibedakan mortalitas akibat penangkapan dan mortalitas alami. Menurut King (1995) laju mortalitas total (Z) adalah penjumlahan laju mortalitas penangkapan (F) dan laju mortalitas alami (M) sehingga ketiga jenis mortalitas tersebut perlu dianalisis. Pendugaan konstanta laju mortalitas total (Z) ikan kembung dilakukan dengan kurva hasil tangkapan yang dilinearkan berbasis data panjang. Kurva hasil tangkapan yang berbasis data panjang yang menggunakan metode Length-Converted Catch Curve di program FISAT II (Pauly, 1983, Gayanilo et al., 2005, Ongkers, 2006).

Hasil penelitian diperoleh nilai dugaan mortalitas total (Z) sebesar 1.50 per tahun, sedangkan nilai mortalitas alami (M) dianalisa dengan menggunakan rumus Empiris Pauly (Sparre 1999) dengan memasukkan nilai $\mathrm{K}=0,17$ per bulan, $\mathrm{L} \infty=49.75 \mathrm{~cm}$ dan $\mathrm{T}=27{ }^{\circ} \mathrm{C}$. dengan demikian diperoleh nilai dugaan $\mathrm{M}=0.48$ per tahun sedangkan nilai laju mortalitas penangkapan (F) diperoleh dengan ( $\mathrm{F}=\mathrm{Z}-$ $\mathrm{M})$ sehingga diperoleh nilai dugaan $\mathrm{F}=1.02$ per tahun. Nilai laju eksploitasi $(\mathrm{E})$ diperoleh dengan $\mathrm{E}=$ $\mathrm{F} / \mathrm{Z}$ sehingga diperoleh $\mathrm{E}=0,68$ per tahun (Gambar 6). 


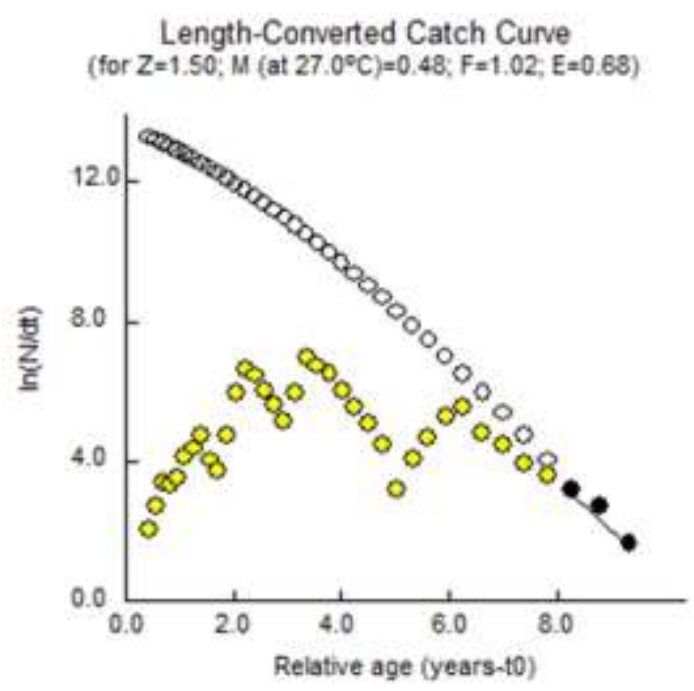

Gambar 6. Kurva Mortalitas

Analisis populasi virtual menggambarkan dinamika mortalitas penangkapan serta dugaan populasi pada setiap kelompok ukuran panjang. Jumlah populasi dan mortalitas penangkapan yang dimiliki ikan kembung pada setiap kelompok ukuran panjang berbeda-beda. Dugaan biomassa ikan kembung di alam melalui analisis VPA adalah sebesar 12.01 ton.pada Gambar 7 menyajikan grafik analisis populasi virtual ikan kembung di Perairan Pulau Ternate.

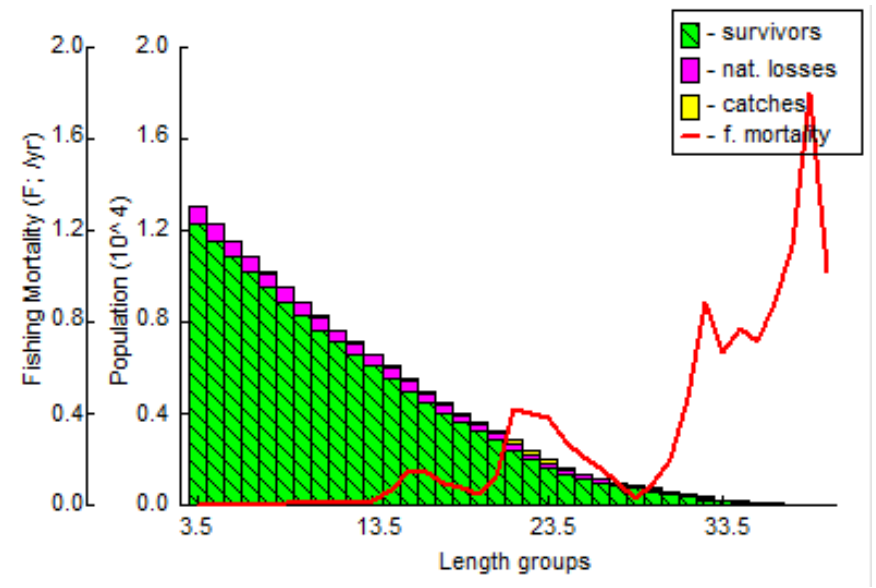

Gambar 7. Analisis populasi virtual ikan kembung di Perairan Pulau Ternate.

Gambar 7. didapat bahwa nilai biomassa ikan kembung yang di daratkan di PPN Ternate dan Pasar Higienis berada pada kisaran panjang mantel $3.5 \mathrm{~mm}$ sampai lebih dari $33.5 \mathrm{~mm}$, dimana jumlah ini mengalami kematian secara alami lebih kecil pada saat ukuran bertambahnya ukuran ikan, selain itu untuk mortalitas penangkapan (F) lebih besar berada pada ukuran panjang ikan lebih besar dari $13.5 \mathrm{~cm}$.

\subsubsection{Yield Per Rekruit dan Tingkat Eksploitasi}

Pendugaan yield per recruitment relative (Y/R) adalah salah satu model yang biasa digunakan sebagai dasar bagi strategi pengelolaan perikanan (Gulland, 1983). Dalam penelitian ini Y/R diduga dengan menggunakan persamaan Beverton dan Holt (Sparre dan Venema. 1999). Fungsi Lc/Lœ dan $\mathrm{M} / \mathrm{K}$ merupakan hal yang menentukan nilai $\mathrm{Y} / \mathrm{R}$ dan $\mathrm{B} / \mathrm{R}$, dimana pada perhitungan $\mathrm{M} / \mathrm{K}$ sebesar 0.45 dan nilai Lc/Loo sebesar 2.82, maka didapat nilai Y/R sebesar 0.02 nilai tersebut menunjukan bahwa jumlah ikan kembung yang masuk ke perairan hanya $20 \%$ yang berhasil di tangkap oleh nelayan, sedangkan nilai B/R didapatkan sebesar 0.5 dimana nilai tersebut menunjukan bahwa biomas yang tersisa dari ikan yang masuk ke perairan sebesar $50 \%$ hal ini menunjukan bahwa tingkat eksploitasi sudah mengalami overfishing atau lebih dari 0.46 (46\%) karena tingkat eksploitasi saat ini sudah mencapai 0.68 . 


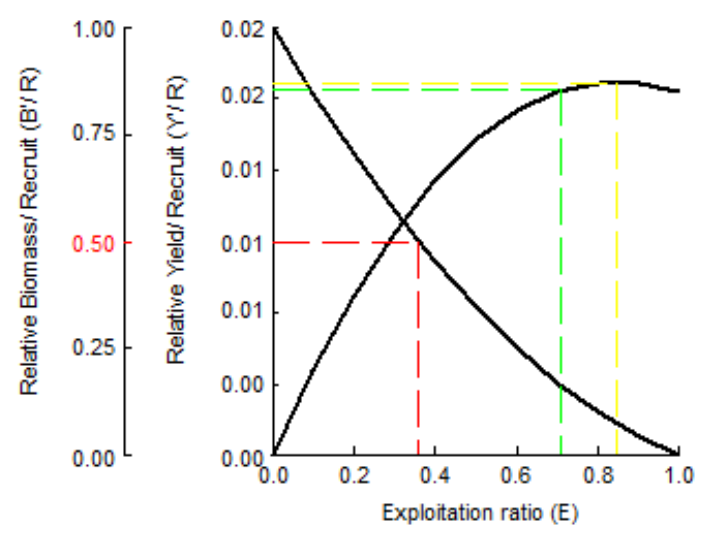

Gambar 8. Grafik Isobar Y/R dan B/R

\section{PENUTUP}

Hasil analisis parameter pertumbuhan ikan kembung yang didaratkan di Kota Ternate didapat bahwa panjang maksimum, koefisien pertumbuhan dan $\mathrm{L} \infty=2.82 \mathrm{~cm}, \mathrm{~K}=0.45$ per tahun dan $\mathrm{t} 0=$ 49.75 dengan mortalitas alami dari ikan kembung, $\mathrm{M}=0.02$ per tahun dan mortalitas penangkapan $\mathrm{F}=$ 13.5 per tahun maka diperoleh nilai tingkat eksploitasi $\mathrm{E}=0.46$. laju eksploitasi tersebut mengindikasikan bahwa tingkat eksploitasi ikan kembung sudah mendekati nilai maksimum $(E=0,50)$. sedangkan nilai $\mathrm{B} / \mathrm{R}$ didapatkan sebesar 0.5 dimana nilai tersebut menunjukan bahwa biomas yang tersisa dari ikan yang masuk ke perairan sebesar $50 \%$ hal ini menunjukan bahwa tingkat eksploitasi sudah mengalami overfishing atau lebih dari 0.46 (46\%) karena tingkat eksploitasi saat ini sudah mencapai 0.68. Populasi ikan kembung dengan nilai biomassa ikan kembung yang di daratkan di PPN Ternate dan Pasar Higienis berada pada kisaran panjang mantel $3.5 \mathrm{~mm}$ sampai $33.5 \mathrm{~mm}$, dimana jumlah ini mengalami kematian secara alami lebih kecil pada saat ukuran bertambahnya ukuran ikan, selain itu untuk mortalitas penangkapan (F) lebih besar berada pada ukuran panjang ikan lebih besar dari $13.5 \mathrm{~cm}$. ini perlu di perhatikan dan dikaji melalui kajian parameter populasi untuk bahan masukan bagi akademisi, pemerintah dan nelayan dalam pemanfaatan ikan kembung diperairan pulau Ternate.

\section{DAFTAR PUSTAKA}

Abubakar S, Riyadi Subur, Irmalita Tahir. 2019. Pendugaan Ukuran Pertama Kali Matang Gonad Ikan Kembung (Rastrelliger sp) di Perairan Desa Sidangoli Dehe Kecamatan Jailolo Selatan Kabupaten Halmahera Barat. Jurnal Bologi Tropis, 19 (1) : 42 - 51.

Alifah, A. N. 2016. Dinamika Populasi Ikan Kembung Lelaki (Rastrelliger Kanagurta Cuvier, 1817) di Perairan Selat Sunda. Skripsi. Fakultas Perikan Dan Ilmu Kelautan. Institut Pertanian Bogor. Bogor.

Aziz, K. A. 1989. Bahan Pengajaran Dinamika Populasi Ikan Departemen Pendidikan dan Kebudayaan. Dirjen Dikti. Pusat Antar Universitas Ilmu Hayat. Institut Pertanian Bogor. Bogor.

Martasuganda, S. 2002. Jaring Insang (Gillnet) Serial Teknologi Penangkapan. Ikan Berwawasan Lingkungan. Jurusan Pemanfaatan Sumberdaya. Perikanan.

Monoarfa, S. 2013. Analisis Parameter Dinamika Populasi Kepiting Bakau (Scylla serata) di Kecamatan Kwandang Kabupaten Gorontalo Utara. Skripsi [Tidak dipublikasikan]. Program Studi Manajemen Sumberdaya Perairan Jurusan Teknologi Perikanan Fakultas Ilmu-Ilmu Pertanian. Universitas Negeri Gorontalo.

Nurhakim S., 1993. Beberapa Parameter Populasi Ikan Banyar (Rastrelliger kanagurta) di Perairan

Laut Jawa. Jurnal Penelitian Perikanan Laut. Hal 64-75. Pauly, D. 1983. A. Selection of Sample Method for Assessment Tropical Fish Stock. Fao Fish Tech. New York.

Saanin H. 1968. Taksonomi dan Kunci Identifikasi Ikan 1 dan 2. Binacipta. Bogor. $508 \mathrm{hlm}$.

Suhendrata, T dan E. M. Amin. Pendugaan Pertumbuhan dan Pola Penambahan Baru Ikan Kembung Lelaki (R kanagurta) di Perairan Selat Madura. Jurnal Penelitian Perikanan Laut No. 54, Hal 59-64. 
Sunarjo. 1990. Analisa Parameter Pertumbuhan Ikan Layang Deles (Decapterus macrosoma Blkr) di Perairan Laut Jawa Bagian Timur. (Skripsi) Fakultas Peternakan Universitas Diponegoro Semarang.

Suwarno, 2010. Biologi Reproduktif, Preferensi Habitat Pemijahan Dan Dugaan Stok Pemijah Ikan Kembung (Rastrelliger brachysoma) di Pantai Utara Jawa. Laporan Program Intensif Peningkatan Kemampuan Peneliti dan Rekayasa. Balai Riset Perikanan Laut. BRPKP, Kementrian Kelautan dan Perikanan.

Von Brandt. 2005. Fish Catching Methods of the World. Edisi ke 4. Otto G, Klaus L. ErdmamD, Thomas W, editor. Oxffort. Blackwell Publishing. 523p. 